\begin{tabular}{|l|l|l||}
\hline \multicolumn{2}{|c|}{ PublisherInfo } \\
\hline \hline PublisherName & $:$ & BioMed Central \\
\hline \hline PublisherLocation & $:$ & London \\
\hline \hline PublisherImprintName & $:$ & BioMed Central \\
\hline \hline
\end{tabular}

\title{
Small-molecule microarrays
}

\begin{tabular}{|l|l|l||}
\hline \multicolumn{2}{|c|}{ ArticleInfo } \\
\hline \hline ArticleID & $:$ & 4554 \\
\hline \hline ArticleDOI & $:$ & $10.1186 /$ gb-spotlight-20020814-01 \\
\hline \hline ArticleCitationID & $:$ & spotlight-20020814-01 \\
\hline \hline ArticleSequenceNumber & $:$ & 220 \\
\hline \hline ArticleCategory & $:$ & Research news \\
\hline ArticleFirstPage & $:$ & 1 \\
\hline \hline ArticleLastPage & $:$ & 2 \\
\hline \hline & & RegistrationDate : 2002-8-14 \\
\hline ArticleHistory & $:$ & OnlineDate \\
\hline \hline ArticleCopyright & $:$ & BioMed Central Ltd2002-14 \\
\hline \hline ArticleGrants & $:$ & \\
\hline \hline ArticleContext & $:$ & 130593311 \\
\hline \hline
\end{tabular}




\section{Jonathan B Weitzman}

Email: jonathanweitzman@hotmail.com

Microarray technologies have been developed to measure differences in mRNA or protein expression levels, but few approaches have addressed the issue of functional enzymatic activity on a genome-wide scale. In the Early Edition of the Proceedings of the National Academy of Sciences, Winssinger et al. describe an innovative microarray application that exploits small molecules to monitor protein function (Proc Natl Acad Sci USA 2002, 10.1073/pnas.172286899). They used libraries of small molecules, each tethered to a peptide nucleic acid (PNA)tag, that can be detected by hybridization to an oligonucleotide microarray. They predict that this technology could be used to screen 400,000 enzyme activity probes in a $300 \mu \mathrm{l}$ volume. To demonstrate proof-of-principle, they monitored caspase activity upon experimentally induced apoptosis and showed that the small molecule inhibitor they identified could prevent cell death.

\section{References}

1. Proceedings of the National Academy of Sciences, [http://www.pnas.org]

2. Profiling protein function with small molecule microarrays., [http://www.pnas.org/cgi/content/ abstract/172286899v1]

3. Peptide nucleic acids and their potential applications in biotechnology. 